\title{
BODYWEIGHT HIGH-INTENSITY INTERVAL TRAINING: A SYSTEMATIC REVIEW
}

TREINAMENTO INTERVALADO DE ALTA INTENSIDADE COM PESO CORPORAL:REVISÃO SISTEMÁTICA

ENTRENAMIENTO POR INTERVALOS DE ALTA INTENSIDAD CON PESO CORPORAL:REVISIÓN SISTEMÁTICA

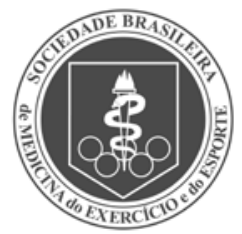

Review Article

ARTIGO DE REVISÃO ARtíCULO de REVISIÓN
Alexandre Fernandes Machado'
(Physical Education Professional)
Maria Luiza de Jesus Miranda'
(Physical Education Professional)
Roberta Luksevicius Rica $^{1}$
(Physical Education Professional) $^{\text {Aylton Figueira Junior }}{ }^{1}$
(Physical Education Professional)
Danilo Sales Bocalini ${ }^{2}$
(Physical Education Professional)

1. Universidade São Judas Tadeu, Department of Post-Graduation in Physical Education, São Paulo, SP, Brazil.

2. Universidade Federal do Espírito Santo, Laboratório de Fisiologia e Bioquímica Experimental , Centro de Educação Física e Esporte, Vitória, ES, Brazil.

\section{Correspondence:}

Danilo Sales Bocalini. Rua Militão Barbosa de Lima, 132, Centro, São Bernardo do Campo, São Paulo, SP, Brazil. 09720-420. bocaliniht@hotmail.com

\begin{abstract}
The objective of this study consisted of describing, through a systematic review, the load control strategies and the different adaptations promoted by bodyweight high-intensity interval training. After selecting articles in the Medline/PubMed, ScienceDirect, SPORTDiscus and Scielo databases, 288 studies were found. However, after applying the inclusion and exclusion criteria only two articles were considered eligible for the systematic review. Of these, the sample of the selected studies was made up of 48 individuals, 31 female and 17 male, ranging in age from 20.3 to 20.5 years. The stimulus time of the exercise protocols used was 20 and 30 seconds, and the recovery time was 10 seconds (passive) and 4 minutes (active), while the total session time ranged from 4 to 18 minutes. Intensity in both studies was "all out", and the weekly frequency was 4 and 3 days, totaling 16 and 12 training sessions in each study. Only one study evaluated changes in body mass and no significant changes were found. In addition, discrepancies between parameters in aerobic fitness and muscle endurance were found between studies. Bodyweight HIIT (High-Intensity Interval Training) protocols use different external load parameters, but the stimulus and recovery times are common variables for the organization of training sessions, with different duration and weekly frequency between sessions, which may have influenced the different adaptations to the parameters of physical fitness between the studies. Level of Evidence l; Prognostic studies - Investigating the effect of patient characteristics on disease outcome.
\end{abstract}

Keyword: Calisthenics; Physical exercise; High-intensity interval training.

\section{RESUMO}

O objetivo do presente estudo consistia em descrever por meio de uma revisão sistemática as estratégias de controle de carga e as diferentes adaptações promovidas pela prática do treinamento intervalado de alta intensidade com o peso corporal. Após seleção de artigos nas bases de dados Medline/PubMed, ScienceDirect, SPORTDiscus e Scielo, encontraram-se 288 estudos, contudo, após a aplicação dos critérios de inclusão e exclusão foram considerados elegíveis apenas dois artigos para a revisão sistemática. Desses a amostra dos estudos selecionados era de 48 indivíduos, sendo 31 do sexo feminino e 17 do sexo masculino com variação da idade entre 20,3 a 20,5 anos. 0 tempo de estímulo dos protocolos de exercício utilizados era de 20 e 30 segundos e o tempo de recuperação de 10 segundos (passivo) e quatro minutos (ativo), o tempo total da sessão variou de quatro a 18 minutos, a intensidade em ambos os estudos era "all out" e a frequência semanal era de quatro e três dias totalizando 16 e 12 sessões de treinamento em cada estudo. Apenas um estudo avaliou as alterações na massa corporal, sendo que não foram encontradas alterações significativas. Além disso, foram encontradas discrepâncias entre os parâmetros na aptidão aeróbia e na resistência muscular entre os estudos. Os protocolos de HIIT (High Intensity Interval Training) com o peso corporal utilizam diferentes parâmetros de carga externa, entretanto, os tempos de estímulo e recuperação são variáveis comuns para a organização das sessões de treinamento, com diferentes duração e frequência semanal entre as sessões, o que pode ter influenciado nas diferentes adaptações aos parâmetros de aptidão física entre os estudos. Nível de Evidência l; Estudos prognósticos - Investigação do efeito da característica de um paciente sobre o desfecho da doença.

Descritores: Calistenia; Exercício físico; Treinamento Intervalado de alta intensidade.

\section{RESUMEN}

El objetivo de este estudio fue describir a través de una revisión sistemática las estrategias de control de carga y las diferentes adaptaciones promovidas por la práctica del entrenamiento por intervalos de alta intensidad con el peso corporal. Después de la selección de artículos en las bases de datos Medline/PubMed, ScienceDirect, SPORTDiscus y Scielo se encontraron 288 estudios, sin embargo, después de aplicar los criterios de inclusión y exclusión fueron elegibles sólo dos artículos para la revisión sistemática. De éstos, la muestra de los estudios seleccionados era de 48 individuos, siendo 31 del sexo femenino y 17 del sexo masculino con variación de edad entre 20,3 a 20,5 años. El tiempo de estímulo de los protocolos de ejercicio utilizados era de 20 y 30 segundos y el tiempo de recuperación de 10 segundos (pasivo) y 4 minutos (activo), el tiempo total de la sesión varió de 4 a 18 minutos, la intensidad en ambos estudios era "all out", y la frecuencia semanal ra de 4 y 3 días totalizando 16 y 12 sesiones de entrenamiento en cada estudio. Sólo un estudio evaluó las alteraciones en la masa corporal, siendo que no fueron encontradas alteraciones significativas. Además, fueron encontradas 
discrepancias entre los parámetros en la aptitud aeróbica y en la resistencia muscular entre los estudios. Los protocolos de HIIT (High Intensity Interval Training) con el peso corporal utilizan diferentes parámetros de carga externa. Entretanto, los tiempos de estímulo y recuperación son variables comunes para la organización de las sesiones de entrenamiento, con diferentes adaptaciones a los parámetros de aptitud física entre los estudios. Nivel de Evidencia l; Estudios pronósticos - Investigación del efecto de la característica de un paciente sobre el resultado de la enfermedad.

Descriptores: Calistenia; Ejercicio físico; Entrenamiento de intervalos de alta intensidad.

\section{INTRODUCTION}

The performance of exercises based on body weight is recognized as a historically used strategy. ${ }^{1}$ However, nowadays, the modality has been gainnig notoriety due to operational facility for its practice. ${ }^{2}$

Addictionally of this trend, the high intensity interval training (HIIT) has been considered as an efficient strategy in the improvement of the physical fitness, ${ }^{3-5}$ body fat reduction ${ }^{5-10}$ and improvement in clinical indicators ${ }^{11-15}$ when it is compared with the moderate intensity training, although there is no significant differences found in other studies ${ }^{9-12}$ between HIIT and continuous and moderate intensity training.

Nevertheless, although the efficiency of HIIT's programs is considered a consensus in literature, the acessibility, the influence of this programs in life style, the long-term repecurssions and the enforcement security remains in discussion. ${ }^{11}$ In this perspective, studies ${ }^{3-5}$ that mix both approaches (HIIT and body weight) can be considered an important strategy in the improvement of the physical fitness parameters.

Thus, the objective of this study was to describe through a systematic review the strategies of external and internal load control during the training sessions and the diferents adaptations promoted in physical fitness parameters by pratice the of high intensity interval training with body weight.

\section{MATERIALS AND METHODS}

After approval of the ethics and research commitee of Universidade São Judas Tadeu (No 1738246), the systematic review of literature was performed using eletronic databases. The eletronic search was conducted in the following databases: Medline/PubMed, Science Direct, SportDiscus e Scielo. The words "High-intense interval training, whole body e calisthenics exercise" were selected as descriptors. At first, the used term was "High-intense interval training", beacuse it is a term that is equally used in DeCs and MeSh Terms. The term "whole body" is different in DeCs and in Entry Terms of the PubMed. The search was performed between November 5th and December 5th, 2016.

The selected articles should fill out the followin criteria: key word in the title and in the abstract, intervention protocol using only body weight exercises combined with the HIIT's strategy, intervention period of at least a week, articles written in English, Spanish and Portuguese and date of publication between January 2006 and November 2016. As exclusion criteria were used the following criteria: cross-sectional and animals studies, vibratory platform studies, articles review, dissertations and theses.

In the identification phase, 288 studies were selected with the "High-intense interval training" term, after" Whole body e calisthenics exercise" descriptors application, three studies were selected. After this selection, the selected articles were wholly obtained and posteriorly examined following the inclusion and exclusion criteria established. A cross-sectional study was withdrawn remaining only two studies, as illustrated in Figure 1.

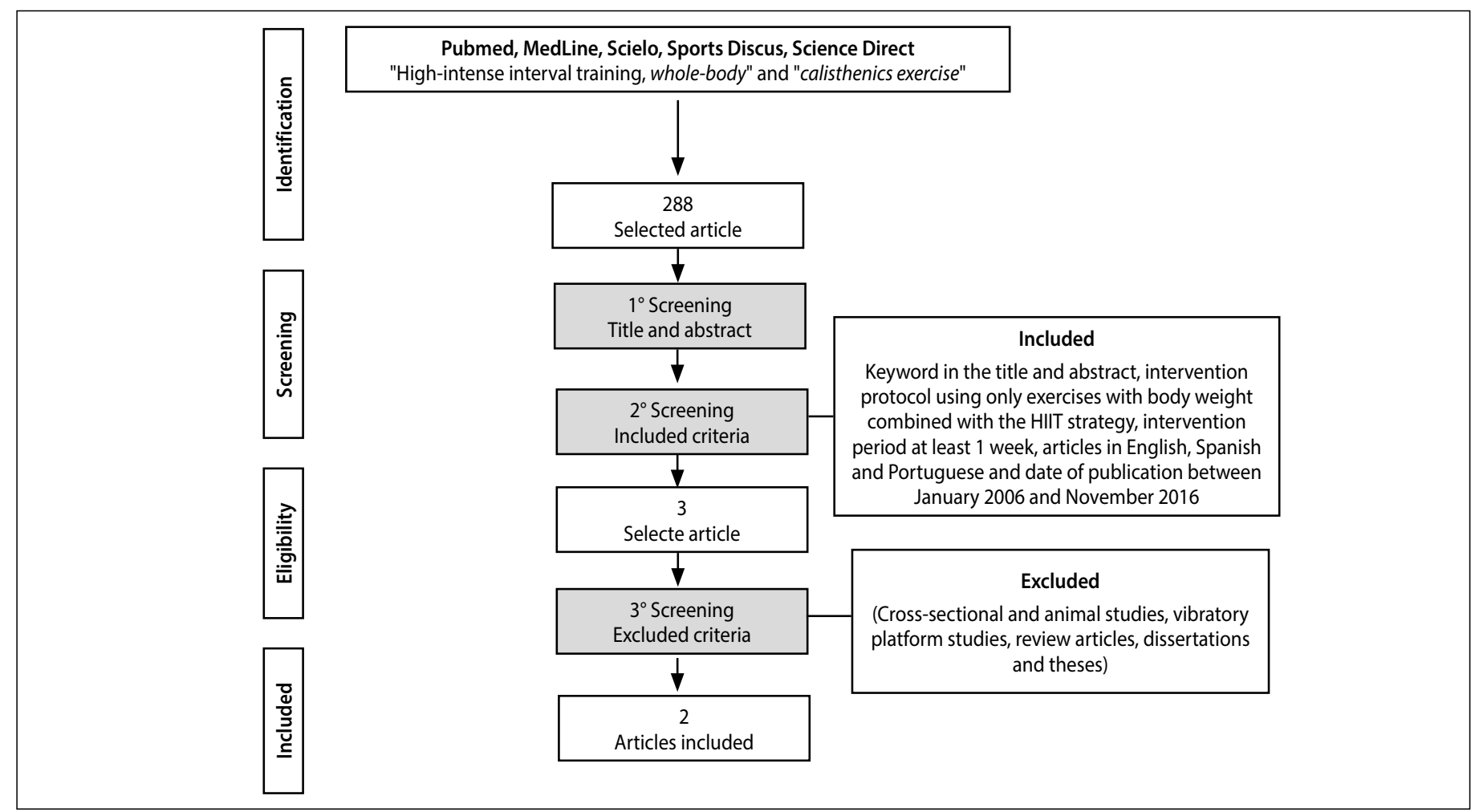

Figure 1. Flow chart of selection of articles. 


\section{RESULTS}

The total number of participants in the selected studies was 48 individuals, being 31 women and 17 men, with mean age variations between 20,3 and 20,5 years old. The exercises burpee, jumping jack, moutain climber e squat trust were used in the studies.

As described in the Table 1, the stimulus time of the exercise protocols used was 20 and 30 seconds and a recovery time of 10 seconds (passive) and 4 minutes (active), the session total time varied between 4 and 18 minutes, the intensity in both study was all out and the weekly frequency was 4 and 3 days, totalizing 16 and 12 training sessions in each study.

Whereas the physical fitness parameters, only McRae et al ${ }^{5}$ study evaluated the exercises program effects on body mass; in that parameters, 16 training sessions was insuficiente to promote significative changes. In relation of neuromotors and metabolic variants, only McRae et al. ${ }^{5}$ study found significative changes as described in Table 2. Furthermore, the same study found significant changes in pleasure perception after HIIT session.

However, although the Gist et $a^{\prime} \mathrm{s}^{3}$ study did not find significant changes in aerobic fitness, differences were found in the lactate peak and in the enforcement perception.

\section{DISCUSSION}

The objective of this study was describe, through a systematic review, the control strategies of external and internal load during the training sessions and the different adaptations promoted in physical fitness parameters by the pratice of high intensity interval training with body weight.

Even if there are only two studies, the main finds of these studies were the similarity of external load controls used in training protocols as stimulus time, recovery time, total time of training session and intervention period and the results discrepancy about adaptations of variables of physical fitness parameters.

From the perspective of physical training, it's known that the training volume is considered an important parameter in adaptive responses, ${ }^{16-19}$ in the study of McRae et al ${ }^{5}$ was not noticed significant changes in aerobic capacity parameters between Endurance and Tabata groups. A possible alternative for this fact could be associated with the proposed volume in the intervention group training session that is lower than Endurance group volume. However, four minutes in high intensity physical activity were enough to promote favorable adaptations in aerobic power and in neuromuscular function compared with the control group.

Table 1. Methodological characteristics.

\begin{tabular}{c|c|c|c|c|c|c|c}
\hline $\begin{array}{c}\text { Author } \\
\text { and year }\end{array}$ & $\begin{array}{c}\text { Effort } \\
\text { time }\end{array}$ & $\begin{array}{c}\text { Recovery } \\
\text { time }\end{array}$ & $\begin{array}{c}\text { Total } \\
\text { time }\end{array}$ & Intensity & $\begin{array}{c}\text { Frequency } \\
\text { week }\end{array}$ & $\begin{array}{c}\text { Total } \\
\text { session }\end{array}$ & $\begin{array}{c}\text { Intervention } \\
\text { days }\end{array}$ \\
\hline $\begin{array}{c}\text { McRae } \\
\text { et al. 2012 }\end{array}$ & $20 \mathrm{sec}$ & $10 \mathrm{sec}$ & $4 \mathrm{~min}$ & all out & 4 days & 16 & 28 \\
\hline $\begin{array}{c}\text { Gist et al. } \\
2015\end{array}$ & $30 \mathrm{sec}$ & $4 \mathrm{~min}$ & $18 \mathrm{~min}$ & all out & 3 days & 12 & 28 \\
\hline
\end{tabular}

Sec: seconds. Min: minutes.

Table 2. Essential characteristics of inlcued studies

\begin{tabular}{|c|c|c|}
\hline & McRae et al. 2012 & Gist et al. 2015 \\
\hline Journal (IF) & Appl. Physiol. Nutr. Metab.(IF: 1,91) & Military Medicine (IF: 1,11) \\
\hline Sample & 22 (female) & 26 (17 male - 9 female) \\
\hline Age (years) & $20.3 \pm 1.4$ & $20.5 \pm 1.7$ \\
\hline Experimental design & $\begin{array}{l}\text { Protocol - } 8 \text { sets with } 20 \text { seconds of a single exercise (burpees, jumping jacks, } \\
\text { mountain climbers, or squat thrusts) separated by } 10 \text { s of rest per session per- } \\
\text { formed } 4 \text { times a week. Endurance protocol - } 30 \text { minutes of racing with intensity } \\
\text { corresponding to } 85 \% \text { of maximal heart rate obtained in the maximum VO2 test. } \\
\text { Protocol control - maintenance of physical activities that practice regularly }\end{array}$ & $\begin{array}{l}\text { Protocol - } 4 \text { to } 7 \text { sets with } 30 \text { seconds of all out exercise with } 4 \text { minutes } \\
\text { of active recovery being performed } 3 \text { times a week. } \\
\text { Fitness Protocol - Army Physical Test (APFT) - } 2 \text { minutes pulled on the bar, } \\
2 \text { minutes abdominal rower and } 3200 \text { meters running being performed } \\
3 \text { times a week. }\end{array}$ \\
\hline Exercise selected & Burpee, Jumping jack, Moutain Climber and Squat trust. & Burpee \\
\hline Results & $\begin{array}{l}\text { Significant increment on } \mathrm{VO}^{2} \text { max and maximal repetitions compared to } \\
\text { control group, however, without statistical significance compared to en- } \\
\text { durance group. }\end{array}$ & $\begin{array}{l}\text { Increment (not statistically) on aerobic and anaerobic capacity in both } \\
\text { group. Statistical differences on muscular parameters between the } \\
\text { groups at the pre- and post-intervention. }\end{array}$ \\
\hline
\end{tabular}

Another important parameter in physical training sessions is the sesstudies reported in literature ${ }^{15-21}$ which has the total during about HIIT training session between 4 and 32 minutes. Furthermore, it is already well established that this duration is enough to promote biometrics adaptations and increase physical fitness ${ }^{5,7,13-15}$ as reported in studies of this review.

Between adaptive mechanisms from the training process, it is known that training load takes great responsibility.22 The training load is conceptually composed by the stimulus that compose the training session, further this parameters is considered an important variable in physical exercise control and can be monitored internally and externally. ${ }^{23,24}$ The internal training load correspond to acute physiological responses provided by exercises. ${ }^{22}$ The greater the internal load of the training, the greater the adaptation on the training, ${ }^{25}$ which has as the main variables: heart rate during the exercise, heart rate immediately after the exercise, lactato concentration measured immediately after the exercise, maximum $\mathrm{VO}_{2}$ during exercise and subjective perception of effort. ${ }^{22-28}$

In HIIT training, the main internal load parameters quoted by literature ${ }^{22-28}$ corresponds to effort perception, heart rate and maximum $\mathrm{VO}_{2}$. In the review, only the studies of Gist et al. ${ }^{3}$ e McRae et al. ${ }^{5}$ used effort perception as intensity monitoring parameter during training session, even though it had all out load propose. total during of training session has been quite used. ${ }^{7,21,26}$ The selected studies in this review used the ratio of $1: 1 / 2^{5}$ and $1: 8 .^{3}$ Such intervals are in line with previous studies. ${ }^{15,19,20}$

In Gist et al study, ${ }^{3}$ significant differences in aerobic capacity between experimental and control groups were not found, however the sample consisted of active military individuals wich may have influenced the experimente result because of participants training level. The trainability is a component that influences the training adaptations, ${ }^{23,24}$ therefore it must be considered independent of experimental desing of studies. ${ }^{22}$ Beyond that the discrepancy between the results in the variables of physical fitness established between both studies can be attributed to difference between the external load parameters used between the studies, especially in the number of weekly sessions and the duration of the recovery interval.

Limitations must be consider in this study, being them the number of studies available in literature as well as the organization of experimental protocols used. These informations do not make possible any conclusion about adaptative mechanisms in anthropometrics parameters. Furthermore even with great researches numbers about HIIT physiological impact, there are still gaps in knowledge about practical enforcement of HIIT with body weight, either in cost effectiveness relation for physical fitness programs, as suggested by Gray, ${ }^{11}$ or in variables manipulation of exercise session as load control, session during, weekly frequency and exercise selection. sion duration. ${ }^{18,20-22}$ The results found in this review agree with previous

Additionally, the ratio of recovery time about effort time and also the 


\section{CONCLUSION}

The protocols of HIIT with body weight use many different external load parameters, the stimulus and recovery time for each cycle are common variables for the training sessions organization, however, with different duration and weekly frequency between sessions, which could have influenced in different adaptations in physical fitness parameters between the studies.

\section{ACKNOWLEDGMENT}

The authors thank CAPES (Personnel Development Coordination Higher Education) for financial support for Machado AF and RICA RL. The support is not exercised by the publication decision, as well as in the preparation of the article.

All authors declare no potential conflict of interest related to this article.

AUTHORS' CONTRIBUTIONS: Each author made significant individual contributions to this manuscript. JPP (0000-0003-4763-9410)* BM (0000-0001-6293-5571)* and ACA (0000-0002-2527-2163)*: were the main contributors to the writing of the manuscript. JPP, BM, JB (0000-0001-7038-0561)*, WM (0000-0002-8077-5417)*, RS (0000-0001-57818928)* and JGC (0000-0002-0263-81 18)*: participated actively in the collection of data. AJH (0000-0001-8645-3956)*, JCS (0000-0002-3646-3387)* and ACA contributed to the experimental design and critical review of intellectual content and operational implications. All authors contributed to the intellectual concept of the study and approved the final version of the manuscript. * ORCID (Open Researcher and Contributor ID).

\section{REFERENCES}

1. Azevedo CB, Santos RM. Corpo, criança e escola: aspectos da cultura escolar dos grupos escolares norte-rio-grandense. Mneme: Revista de Humanidades. 2015;16(37):91-126.

2. Aliajas RDR, Torre AHD. Calistenia: volviendo a losorígenes. Emásf, Revista Digital de Educación Física, 2015;6(33):87-96.

3. Gist NH, Freese EC, Ryan TE, Cureton KJ. Effects of low-volume, high-intensity whole-body calisthenics on Army ROTC cadets. Military medicine, 2015;180(5):492-8.

4. Gist NH, Freese EC, Cureton KJ. Comparison of responses to two high-intensity intermittent exercise protocols. J Strength Cond Resh, 2014;28(11):3033-40.

5. McRae G, Payne A, Zelt JGE, Scribbans TD, Jung ME, Little JP. et al. Extremely low volume, whole-body aerobic-resistance training improves aerobic fitness and muscular endurance in females. Appl Physiol Nutr Metab, 2012;37(6):1124-31.

6. Germano MD, Sindorf MAG, Silva CE, Evangelista AL, Bocalini DS, Lopes CR. High intensity interval training: cardiorespiratory adaptations, metabolic and performance. Inter J Sports Sci. 2015;5(6):240-7.

7. Buchheit $M$, Laursen PB. High-intensity interval training, solutions to the programming puzzle. Sports Med, 2013;43(5):313-38.

8. Gibala MJ, Gillen JB, Percival, ME. Physiological and health-related adaptations to low-volume interval training: influences of nutrition and sex. Sports Med, 2014;44(2):127-37.

9. De Feo P. Is high-intensity exercise better than moderate-intensity exercise for weight loss? Nutr Metab Cardiovasc Dis, 2013;23(11):1037-42.

10. Gillen JB, Martin BJ, MacInnis MJ, Skelly LE, Tarnopolsky MA, Gibala MJ. Twelve weeks of sprint interval training improves indices of cardiometabolic health similar to traditional endurance training despite a five-fold lower Exercise volume and time commitment. PloS One. 2016;11(4):e0154075.

11. Gray SR, Ferguson C, Birch K, Forrest LJ, Gill JM. High-intensity interval training: key data needed to bridge the gap from laboratory to public health policy. Br J Sports Med. 2016;50(20):1231-2.

12. Keating SE, Machan EA, O'Connor HT, Gerofi JA, Sainsbury A, Caterson ID, et al. Continuous exercise but not High intensity interval training improves fat distribution in overweight adults. J Obes. 2014;2014:834865.

13. Gibala MJ, Little JP. Just HIT it! A time-efficient exercise strategy to improve muscle insulin sensitivity. J Physiol. 2010;588(Pt 18):3341-2.

14. Gibala MJ, Gillen JB, Percival, ME. Physiological and health-related adaptations to low-volume interval training: influences of nutrition and sex. Sports Medicine. 2014;44(Suppl 2):127-37.
15. Rozenek R, Salassi JW, Pinto NM, Fleming JD. Acute cardiopulmonary and metabolic responses to high-intensity interval training protocols using $60 \mathrm{~s}$ of work and $60 \mathrm{~s}$ recovery. J Strength Cond Res. 2016;30(11):3014-23.

16. Schoenfeld B, Dawes J. High-intensity interval training: applications for general fitness training. Strength Cond J. 2009:31(6):44-6.

17. Gibala MJ, McGee SL. Metabolic adaptations to short-term high-intensity interval training: a little pain for a lot of gain? Exerc Sport Sci Rev. 2008;36(2):58-63.

18. Machado AF, Nunes RA, Vale RG; Figueira Junior A, Bocalini DS. Body weight based in high intensity interval training: the new calisthenics? Man Ther Posturology Rehabil J. 2017;15:1-5.

19. Osawa Y, Azuma K, Tabata S, Katsukawa F, Ishida H, Oguma Y, et al.. Effects of 16-week high-intensity interval training using upper and lower body ergometers on aerobic fitness and morphological changes in healthy men: a preliminary study. Open Access J Sports Med. 2014;5:257-65.

20. Tabata I, Irisawa K, Kouzaki M, Nishimura K, Ogita F, Miyachi M. Metabolic profile of high intensity intermittent exercises. Med Sci Sports Exerc. 1997;29(3):390-5.

21. Tucker WJ, Sawyer BJ, Jarret CL, Bhammar DM, Gaesser GA. Physiological responses to high-intensity interval exercise differing in interval duration. J Strength Cond Res. 2015;29(2):3326-35.

22. Pinho RW, Braz TV, Cruz WA, Santos AB, Ribeiro C, Germano MD, et al. Efeito da magnitude de carga interna de treinamento sobre o VO2MÁX de mulheres adultas. R Bras Ci e Mov. 2016;24(1):43-51.

23. Borin JP, Prestes J, Moura NF. Caracterização, controle e avaliação: limitações e possibilidades no âmbito do treinamento desportivo. Revista Treinamento Desportivo. 2007:8(1):6-11.

24. Borin JP, Gomes AC, Leite GS. Preparação desportiva: aspectos do controle da carga de treinamento nos jogos coletivos. R da Educação Física/UEM. 2008;18(1):97-105.

25. Impellizzeri FM, Marcora SM, Castagna C, Reilly T, Sassi A, laia FM, et al. Physiological and performance effects of generic versus specific aerobic training in soccer players. Int J Sports Med. 2006;27(6):483-92.

26. Buchheit M, Laursen PB. High-intensity interval training, solutions to the programming puzzle. Part II: anaerobic energy, neuromuscular load and practical aplllications. Sports Med. 2013;43(10):927-54.

27. Tiggemann CL, Pinto RS, Kruel LF. A percepção de esforço no treinamento de força. Rev Bras Med Esporte. 2010;16(4):301-9.

28. Mata JD, Oliver JM, Jagim AR, Jones MT. Sex differences in strength and power support the use of a mixed-model approach to resistance training programing. Strength Cond J. 2016;38(2):2-7. 